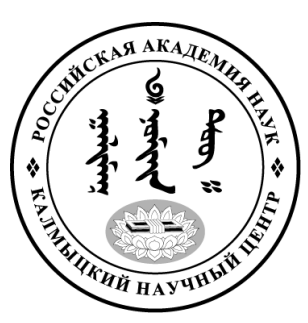

Published in the Russian Federation

Oriental Studies (Previous Name: Bulletin of the Kalmyk Institute for

Humanities of the Russian Academy of Sciences)

Has been issued as a journal since 2008

ISSN: 2619-0990; E-ISSN: 2619-1008

Is. 3, pp. 450-459, 2019

DOI: $10.22162 / 2619-0990-2019-43-3-450-459$

Journal homepage: https://kigiran.elpub.ru

УДК 294.321+930.253

\title{
Из истории комплектования и описания Фонда 8 Научного архива КалмНЦ РАН (по описи В. О. Поляева)
}

\author{
Делями Николаевна Музраева ${ }^{I}$ \\ ${ }^{1}$ Калмыцкий научный центр РАН (д. 8, ул. И. К. Илишкина, 358000 Элиста, Российская Феде- \\ рация) \\ кандидат филологических наук, ведущий научный сотрудник \\ ORCID: 0000-0002-8619-9369. E-mail: deliash@mail.ru
}

\begin{abstract}
Аннотация. Введение. Коллекция письменных памятников КалмНЦ РАН складывалась на протяжении более чем полувекового периода. В настоящий момент мы не располагаем сколько-нибудь подробной историей ее создания (комплектования). В этом вопросе ценными источниками служат разного рода описи, справки, описания, перечни поступлений, а также дарственные записи лиц, передававших в дар институту раритеты из своих личных библиотек. О том, что интересующая нас рукописная коллекция складывалась постепенно, мы можем судить по описям, согласно которым первые образцы текстов стали поступать в начале 1960-х гг., когда институт был восстановлен после периода депортации калмыков. Среди имен первых дарителей следует перечислить такие, как Тугмюд-гавджи, Э. Б. Убушиев, Н. Давуров, В. К. Артаев и др. Определенная часть источников была привезена сотрудниками института из экспедиций. Старописьменные материалы архива КалмНЦ представляют для исследователей-источниковедов большое поле деятельности. Собранные и сохраненные жившими в миру калмыцкими гелюнгами (Тугмюд-гавджи, Э. Б. Убушиев и др.), они донесли до наших дней живое свидетельство бытования буддийской традиции у калмыков на всем протяжении ХХ в. Цель. Данная публикация продолжает исследование письменных источников, поступивших в архив КалмНЦ РАН (на тот момент КНИИИФЭ) от Э. Б. Убушиева. Автор приводит и анализирует опись содержания сборника «Сундуй» из коллекции Э. Б. Убушиева. Статья подготовлена на основе описи В. О. Поляева (Чуматова) (1953-2013), в то время младшего научного сотрудника сектора монголоведения, сделанной им при описании круга источников, поступивших от калмыцкого священнослужителя - Э. Б. Убушиева (Агван Табдана). Работа по составлению описи является первым этапом в изучении определенного сочинения (или коллекции из нескольких сочинений), поскольку подробное описание, оценка важности текста, освещение его содержания, правильная классификация и прочие моменты могут сыграть важную роль в дальнейшем вынесении оценки его культурно-исторической значимости, в последующей его трансляции в культуру современности. Результаты. В результате анализа автор приходит к выводу о том, что большой заслугой священнослужителей-подвижников, передавших свои коллекции рукописных письменных памятников в КалмНЦ РАН, было то, что, согласно их желанию, эти материалы поступили в академический институт, поскольку они нисколько не сомневались и верили в то, что именно ученые-монголоведы и тибетологи смогут донести информацию о них до широких кругов исследователей и интересующихся буддизмом и сохранить ее для народа. Именно таким был востоковед В. О. Поляев (Чуматов). Опись-справка, которую мы предста-
\end{abstract}


вили в данной работе, свидетельствует о нем как о специалисте высокой квалификации, широкой эрудиции, его переводы с тибетского демонстрируют его профессионализм, а также яркий талант переводчика, не лишенного поэтического дара. Представленные в статье документы также демонстрируют постановку архивного дела в институте и большой интерес, с которым его руководство относилось к буддийскому наследию калмыков.

Ключевые слова: буддизм, архив КалмНЦ РАН, опись, В. О. Поляев (Чуматов), Фонд редких рукописей (Фонд-8), коллекция Э. Б. Убушиева, сборник «Сундуй», 2-томный ксилограф, тибетский язык

Благодарности: Исследование проведено в рамках государственной субсидии - проект «Устное и письменное наследие монгольских народов России, Монголии и Китая: трансграничные традиции и взаимодействия» (номер госрегистрации: АААА-А19-119011490036-1).

Для цитирования: Музраева Д. Н. Из истории комплектования и описания Фонда-8 Научного архива КалмНЦ РАН (по описи В. О. Поляева). Oriental Studies. 2019;(3): 450-459. DOI: 10.22162/2619-0990-2019-43-3-450-459.

UDC $294.321+930.253$

\title{
Fond 8 of the Scientific Archive of the Kalmyk Scientific Center (RAS): Excerpts from the History of Its Formation and Description (an Insight into V. O. Polyaev's Inventory List)
}

\author{
Delyash N. Muzraeva \\ ${ }^{1}$ Kalmyk Scientific Center of the RAS (8, Ilishkin St., Elista 358000, Russian Federation) \\ Cand. Sc. (Philology), Leading Research Associate \\ ORCID: 0000-0002-8619-9369. E-mail: deliash@mail.ru
}

\begin{abstract}
Introduction. The collection of written monuments contained in the Kalmyk Scientific Center of the RAS has been consistently enriched throughout over half a century. For the time being there is no detailed description of its creation (formation). Valuable sources of information here are different inventory lists, certificates, descriptive reports, lists of deliveries, and donation cover letters by individuals who submitted their personal rare materials to the institute. The inventory lists according to which the first texts arrived in the early 1960s when the institute was reestablished after the return of the Kalmyks - attest to that the manuscript collection has been developed step by step. The list of donators includes such names as Tyugmyud Gavji, E. Ubushiev, N. Davurov, V. Artaev, etc. Some texts were discovered by employees of the Institute during expeditions. Materials in classical scripts contained in the Archive of Kalmyk Scientific Center may serve as a tremendous research field for academic historiographers. The former had been collected and preserved by Kalmyk 'lay' gelongs (Tyugmyud Gavji, E. Ubushiev and others), remaining a living evidence that the Kalmyk Buddhist tradition did survive the whole of the dramatic $20^{\text {th }}$ century. Goals. The paper provides another insight into written sources delivered to the Archive of Kalmyk Scientific Center (then Kalmyk Research Institute of History, Philology and Economics) by E. Ubushiev (Agvan Tabdan). The article describes and analyzes the inventory list of the gZungs 'dus collection from E. Ubushiev's personal archives through the use of records by V. Polyaev (Chumatov) (1953-2013), then a junior research associate to have described texts received from the Kalmyk Buddhist priest. Such inventory recording is the first stage within a series of arrangements aiming to investigate a certain writing (or collected writings) since somewhat detailed description, assessment of significance of a text, representation of its contents, accurate classification and other aspects may be critical to further evaluations of its culturaland-historical weight, to its further introduction into contemporary cultural discourse. Results. The work concludes the tremendous merit of the enthusiastic Buddhist priests who donated their personal archives (containing manuscript monuments) was that - according to wills of theirs - the materials were delivered to the academic institute since they believed those were Mongolists and Tibetologists who could transmit corresponding messages to other researchers and Buddhist-minded citizens, and thus preserve the wisdom for the people in general. And this was well completed by the Orientalist V.
\end{abstract}


Polyaev. The presented inventory record characterizes him as an accomplished and erudite specialist with expertise in Tibetan and somewhat bright poetic translation talent. The reviewed documents also illustrate the institute's archive keeping activities were held at a high professional level, and the directorate showed great interest in the preservation of the Kalmyk Buddhist heritage.

Keywords: Buddhism, Archive of KalmSC RAS, inventory list, V. O. Polyaev (Chumatov), Fond for Rare Manuscripts (Fund-8), E. Ubushuev's collection, gZungs 'dus collection, two-volume woodblock print, Tibetan language

Acknowledgements: Research was performed within a government subsidy — project name 'Oral and Written Heritage of Mongolic Peoples of Russia, Mongolia and China: Cross-Border Traditions and Interactions' (State Reg. No. AAAA-A19-119011490036-1)/

For citation: Muzraeva D. N. Fond 8 of the Scientific Archive of the Kalmyk Scientific Center (RAS): Excerpts from the History of Its Formation and Description (an Insight into V. O. Polyaev's Inventory List). Oriental Studies. 2019;(3): 450-459. DOI: 10.22162/2619-0990-2019-43-3-450-459.

Собрание буддийских письменных источников обширно ввиду того, что сам канон насчитывает большое разнообразие текстов: два свода «Ганджур» и «Данджур» с большим количеством текстов, тем не менее, расклассифицированых, распределенных по определенным разделам, т. е. прошедших определенную систематизацию в зависимости от жанра, назначения, соотнесенности с определенным культом, божеством (или группой божеств) пантеона; важна также и приверженность той или иной религиозной школе, направлению с их кругом почитаемой (сакральной, культовой) литературы.

Не все храмы обладали подобными каноническими собраниями в полном объеме. Некоторые хурулы владели лишь небольшими, подчас разрозненными, коллекциями, в которых отразились все указанные выше моменты. Те образцы текстов, которые дошли до наших дней, сохранились не в полном объеме и подчас фрагментарно. Поэтому их описание, классификация, каталогизация, в определенной степени облегчающие их изучение, перевод, а значит, и введение в научный оборот, являются актуальными задачами отечественного востоковедения.

Коллекция письменных памятников Калмыцкого научного центра Российской академии наук (далее - КалмНЦ РАН) складывалась на протяжении более чем полувекового периода. В настоящий момент мы не располагаем сколько-нибудь подробной историей ее создания. В этом во- просе ценными источниками служат разного рода описи, справки, описания, перечни поступлений, а также дарственные записи лиц, передававших институту раритеты из своих личных библиотек. О том, что рукописная коллекция складывалась постепенно, мы можем судить по описям, согласно которым первые образцы текстов стали поступать в начале 1960-х гг. Это время, когда институт был восстановлен после периода депортации калмыков. Среди первых дарителей следует перечислить такие имена, как Тугмюд-гавджи, Э. Б. Убушиев, Н. Давуров, В. К. Артаев и др. Определенная часть источников была привезена из экспедиций.

В 1980 г. рукописный фонд пополнился личной библиотекой Тугмюд-гавджи (О. М. Дорджиева) (1887-1980), известного буддийского священнослужителя. Коллекция Тугмюд-гавджи составила Фонд-15 (ФД-15 или Фонд О. М. Дорджиева), который в свою очередь включает три описи. Состав и содержание этой коллекции отражены в серии публикаций [Чуматов 1983; Музраева 1999; Орлова 2002; и др.].

Личность Тугмюд-гавджи и его деятельность как священнослужителя, переводчика и собирателя восточных книг получили определенное освещение в научных публикациях [Буддийская традиция 2008] и СМИ.

На сегодняшний день сохранилось мало сведений о других фондообразователях. Эту информацию приходится собирать по крупицам, обращаясь к их родственникам и близким. Очень важные данные о време- 
ни поступления того или иного источника, о его владельце, обстоятельствах и мотивах передачи в дар институту и прочем мы неожиданно для себя обнаружили в самих письменных памятниках. О том, каким предстает личность дарителя Э. Б. Убушиева (1905-1981) согласно дарственным записям, мы писали в одной из предыдущих статей [Музраева 2018б].

Данная публикация продолжает исследование письменных источников, поступивших в архив КалмНЦ РАН (на тот момент КНИИИФЭ $\left.{ }^{1}\right)$ от Эрдни Бакалдыковича Убушиева. Она подготовлена на основе описи В. О. Поляева ${ }^{2}$ (1953-2013), в то время младшего научного сотрудника сектора монголоведения, сделанной им при описании новых поступлений.

Эти описи, с одной стороны, демонстрируют постановку архивного дела в институте, с другой, являются первым этапом в вопросе изучения определенного сочинения (или коллекции из нескольких сочинений), поскольку не вызывает сомнения, что подробное описание, оценка важности текста, освещение его содержания, правильная классификация и прочие моменты играют важную роль в последующем вынесении оценки его культурно-исторической значимости, определяют дальнейшую судьбу в последующей его трансляции в культуру современности. Это особенно актуально для Калмыкии, где в последние десятилетия мы наблюдаем возрождение буддийских традиций как одной из составляющих культуры калмыков.

Работа В. О. Поляева представляет большой интерес как одна из первых публикаций в плане камеральной обработки специалиста-тибетолога и в то же время демонстрирует его эрудицию и талант переводчика. Сегодняшним поколениям источниковедов очень повезло, что у истоков каталогизации рукописного собрания КалмНЦ РАН стояла такая личность. Его последующие работы (статья-обзор коллекции старописьменных тибетских и монгольских источников КНИИИФЭ, а также карточный каталог) стали незаменимыми помощниками для всех последующих поколений востоковедов. Этот

\footnotetext{
${ }^{1}$ Калмыцкий научно-исследовательский институт истории, филологии и экономики.

${ }^{2}$ В последующем сменил фамилию на Чуматов.
}

каталог, несмотря на лаконизм картотеки, позволяет составить общее представление о коллекции.

Ниже мы приводим текст описей поступлений от Э. Б. Убушиева, составленных В. О. Поляевым. Эти описи являются копиями машинописного текста, сделанными с помощью копировальной бумаги фиолетового цвета. Их содержание - описание двухтомного ксилографического издания сборника «Сундуй» на тибетском языке. Оно дано в кратком виде, поскольку в нем отображены не все тексты, вошедшие в двухтомное издание. Данная публикация вызывает большой интерес еще и потому, что позволяет сопоставить два разных ксилографических издания сборника «Сундуй» ${ }^{3}$.

\section{Поступления ${ }^{4}$ от Убушиева Э. Б. ${ }^{5}$} (7 апреля $1979^{6}$ года)

[Маргиналии слева от титула сочинения сделаны карандашом:] «Принято 13/ VIII - 80 г. [ручкой:] Фонд 8. Опись 1. № 93. 203 л. $(54,5 \times 12)$. [карандашом:] Маньджушри-нама-самгити ${ }^{7}$.

$$
\text { [c. 1] }
$$

TOM I. Byin brlabs dngos grub ba bkra sh[i]s cha sar bebs pa'// bstan 'gros (2) phan bde 'di phyang tshal rgyas pa'i phyir / ngo mtshar jam gling sa steng dkon mchog gzungs mdo brgya dang drug bcu rtsa ldan bzhugs sto

$$
[=s o] / / \beta
$$

3 Описание 1-томного ксилографического издания, поступившего в архив КалмНЦ РАН от Э. Б. Убушиева, дано нами в предыдущей публикации [Музраева 2018а].

4 Согласно маргиналиям (на полях двух описей), составленным В. О. Поляевым (Чуматовым), рукописи поступили в Научный архив КНИИИФЭ 13 августа 1980 г. Все они вошли в состав Фонда-8 (Фонда редких рукописей), составили опись 1 , ед. хр. 93-94. Текст описей печатается курсивом, в нем сохранена пунктуация, разбивка материала на пункты, сделанная В. О. Поляевым.

5 Эрдни Бакалдыковича.

${ }^{6}$ Переправлено ручкой на «1980 г.».

${ }^{7}$ «Маньджушри-нама-самгити» — это санскритское название сочинения «Истинное произношение имени Манджушри» (тиб. 'phags pa 'jam dpal gyi mtshan yang dag par brjod pa), которое помещено в начале 1-го тома.

${ }^{8}$ Название сочинения приводится по-тибетски от руки, шариковой ручкой фиолетовыми чернилами [gZungs 'dus I]. 
Перевод: " 160 сутр 9 и дхарани ${ }^{10}-\partial р а-$ гоченность и чудо этого мира, снизомедшее на землю в виде благословенного дождя на благо постоянного проиветания Сада Учения» (общее название).

Ксилограф китайского издания на тибетском языке; формат большой тибетский; всего в томе 203 листа (198л. - текст, 5 л. - гарчик $\left.{ }^{11}\right)$, текст полный. (Каталог и колофон).

Данные колофона:

1) ... Дайчин Юнден-хан ${ }^{12}$ написал [памятник] в средний осенний месяи года мыши; во дворие А-на-тинг-мун, в западной стороне пути, в Цищика$p e^{13}$ [Хэйлунизян] успешно завершил...

2) Наивысшие сутры и дхарани из монастыря Самье ${ }^{14}$ полностью собраны Ми-ж⿻аң-лег-бой из необходимости исполнить дело всех времен...

... эти драгоченные тома, это ожерелье океана всех сторон света - сокровищница и радость богов и людей трех миров... в твердокаменном снежном Тибете сделал Тараната ${ }^{15} u$, будучи приглашенным ко двориу китайского [императора], тщательно отобрал, сделал необходимым сокращения и прочее; мелкие сутры и тан-

9 Сутры - жанр буддийской литературы. Принято считать, что проповеди Будды представлены в виде сутр.

${ }^{10}$ Дхарани - тексты, включающие мантры, священные стихи.

11 От тиб. dkar chag 'оглавление, содержание'.

12 Дайчин Юнден-хан... - Здесь речь идет об императоре маньчжурской династии Юнчжэне (Юнджэне) в Китае. Время его правления определяется периодом 1723-1735 гг.

${ }^{13}$ Цицикар - город в сев.-вост. части Китая (пров. Хэйлунцзян), основан в 1691 г., во времена маньчжурской династии Цин являлся одним из плацдармов для расширения ее владений.

${ }^{14}$ Самье - название первого буддийского монастыря в Тибете, основанного в 775-779 гг.

${ }^{15}$ Тараната (или Таранатха) (1575-1634) известный тибетский мыслитель; является инициатором создания сводного собрания текстов, которые необходимы были священнослужителям в философской и религиозной практике. Такой сборник хорошо известен под условным кратким названием «Сундуй» (от тиб. gZungs 'dus), неоднократно издавался ксилографическим способом в буддийских центрах. mры ${ }^{16}$ собраны из необходимости в отдельные тома и оставлены без сокращения».

В первом томе - отдел сутр и дхарани, входяший в «тантру»: [каталог] $]^{17}$

1) Манджушри нама самгити (Маньджушрин $^{18}$ зарлиг) ${ }^{19}$ (Завершение всех полезных заслуг).

$$
\text { [c. 2] }
$$

2) «Ценд Аюуш - беспредельная 108-членная мудрость». (- дхарани о бессмертии и славе)» ${ }^{20}$.

3) «Победоносная дхарани ,, Украшение maтхагат"» ('Зонт святых') (-

16 Тантры - раздел канонического свода Ганджур (Кангьюр).

${ }^{17}$ Далее В. О. Поляев приводит перечень сочинений, включенных в 1-й том, в соответствии с тем, как они отмечены в гарчаке (оглавлении), который представляет собой текст на нескольких листах, состоящий из сплошного перечисления кратких названий сочинений из 1 и 2-го томов описываемого двухтомного ксилографа «Сундуй», поступившего в архив КалмНЦ РАН от Э. Б. Убушиева в 1980 г. В приводимом перечне разделы оглавления имеют нумерацию в виде букв тибетского алфавита, начиная с ka, kha, ga, nga и т. д., в своей справке В. О. Поляев нумерует разделы арабскими цифрами со скобкой. В тех случаях, когда названия сочинений приводятся без нумерации, это означает, что они содержатся в одном разделе. Далее номер раздела, выделенный жирным начертанием, указывается в круглых скобках.

${ }^{18}$ Манджушри - бодхисаттва мудрости.

${ }^{19}$ Тиб. 'phags pa 'jam dpal gyi mtshan yang dag par brjod pa ('Истинное произношение имени Манджушри'). Такое же название зафиксировано в тексте, с которого начинается 1-й том. Данное сочинение составляет раздел (ka).

20 Тиб. 'phags pa tshe dang ye shes dpag tu med pa'i mtshan brgya rtsa brgyad pa. Ценд Аюуш - монгольский (ойратский) эквивалент имени Амитаюса - Будды (Бодхисаттвы) долгой жизни; тесно связанного с Буддой Амитабхой, являющегося одной из его форм (kha).

21 Здесь В. О. Поляев дает перевод титула сочинения, согласно оглавлению (тиб. de bzhin gshegs ba'i gtsug tor rnam par rgyal ba'i gzungs rtogs pa dang), которое включает «поучения» и «магтал»: 1) тиб. de bzhin gshegs pa'i gtsug tor rnam par rgyal ba'i gzungs rtogs ра ('Дхарани Ушнишавиджаи'); 2) тиб. gtsug tor rnam par rgyal ba la bstod pa ('Гимн Ушнишавиджае'); оба сочинения входят в раздел (ga). 
поучения и магтал Чандрагомина ${ }^{22}$.

4) «Победоносньй зонт о полном усмирении всех, кто живет неверно» ${ }^{23}$. Поучения о победоносном зонте в 2-х частях.

Чистый (святой) зонт ${ }^{24}$.

Сто тысяч украшений бодисатв ${ }^{25}$.

Тайна, исиеляющая убогих ${ }^{26}$.

Сущность причинно-следственных связей ${ }^{27}$.

5) Методы созериания Белозонтичной Tары (Дугар) ${ }^{28}$.

Магтал (восхваление) Дугар 29.

Пьлаюшая Дугар (докиит)

6) Будда, Победоносно прочедший (Шакья Муни ${ }^{31}$.

7) Сутра богини Пал-Чен-мо

8) Дхарани Обладающего богатством $(\text { Кубера - . .) })^{33}$

Исиеление недуга ${ }^{34}$.

Обладающий пальцами ${ }^{35}$.

Юм-источник всего Учения ${ }^{36}$.

22 Чандрагомин - знаменитый индийский ученый и поэт первой половины VII в.

${ }^{23}$ Тиб. ngan 'gro thams cad yongs su sbyongs ba'i gtsug tor rnam rgyal ('Ушнишавиджая, полностью очищающая от всех неблагих перерождений') (nga).

24 Тиб. gtsug tor dri med ('Непорочная Ушниша') (nga).

${ }^{25}$ Тиб. byang chub brgyan 'bum ('Украшения Бодхи (Просветления)' (nga).

${ }^{26}$ Тиб. gsang ba ring bsrel ('Тайные реликвии (частицы шарира)') (nga).

27 Или 'Сущность взаимообусловленного происхождения' (тиб. rten 'brel snying po) (nga).

${ }^{28}$ Тиб. gtsug tor gdugs dkar mchog tu grub ba (=pa) dang ('Обладающая белым зонтом') (са).

${ }^{29}$ Тиб. gtsug tor gdugs dkar can la bstod pa ('Гимн Обладающей белым зонтом') (са). (ca).

${ }^{30}$ Тиб. gtsug tor 'bar ba ('Пламенная ушниша')

31 Тиб. bcom ldan 'das kyis (=gyi) mtshan brgya rtsa brgyad pa ('Сто восемь имен Бхагавана («Ушедшего с победой»)') (cha).

${ }^{32}$ Тиб. dpal chen mo'i mdo ('Сутра [богини] Палченмо («Обладающей великой славой»)') (ra).

${ }^{33}$ Так в тексте. Кубера - бог богатства. Тиб. dbyig dang ldan pa'i gzungs (la).

${ }^{34}$ Тиб. 'phags pa dug sel ba ('Устраняющее действие яда') (la).

${ }^{35}$ Тиб. 'phags pa sor mo can ('Обладающая перстами (пальцами)') (la).

${ }^{36}$ Тиб. chos thams cad kyi yum ('Мать всех дхарм') - это дхарани (la).
Драгоченность, украшающая голову ${ }^{37}$. Восхваление знающему шесть святых букв ${ }^{38}$.

9) Праджняпарамита 25-тысячная ${ }^{39}$. (Праджсняпарамита) 100-тысячная для запоминания ${ }^{40}$.

8-тысячная для запоминания ${ }^{41}$.

2 части - для усвоения 6 добродетелей (парамит) $)^{42}$.

10 добродетелей - для достижения ${ }^{43}$.

Дхарани для достижения 4 неизмеримblx ${ }^{44}$.

Праджняпарамита 8-тысячная для восприятия (Жадамва) $)^{45}$.

${ }^{37}$ Тиб. 'phags pa gtsug gi nor bu ('Чинтамани (драгоценный камень) в короне') - название дхарани. Раздел (la).

${ }^{38}$ Так передано тиб. 'phags pa yi ge drug pa'i rig sngags ('Видьямантра (мантра знания) шести слогов'). Под шестью слогами понимается мантра бодхисаттвы Авалокитешвары «ом maṇi padme hūmi» (la).

39 Здесь также речь идет о 'Дхарани 25-тысячной Праджняпарамиты' (тиб. 'phags pa shes rab kyi pha rol du (=tu) phyin pa stong phrag nyi shu lnga pa bzung bar 'gyur ba), a не о самом праджняпарамитском тексте (sha).

40 Здесь дан перевод краткого названия сочинения, согласно тому, как оно отображено в оглавлении (тиб. stong phrag brgya pa bzung bar 'gyurba '100-тысячная Праджняпарамита') (sha).

${ }^{41}$ Речь идет о тексте «Праджняпарамита в 8 тысяч шлок (строф)» (sha).

${ }^{42}$ Тиб. phar phyin drug bzung bar ' gyur ba gnyis. В этом тексте речь идет о шести парамитах или шести совершенствах бодхисаттвы или архата. В. О. Поляев подбирает к данному термину эквивалент перевода «добродетели» (sha).

${ }^{43}$ Титул данного сочинения в гарчаке приводится следующим образом: тиб. phar phyin btsu (=bcu) thob par 'gyur ba ('Достижение (обретение) десяти парамит'). В самом же тексте 1-го тома он отмечен как 'Дхарани о десяти парамитах' (тиб. pha rol tu phyin pa bcu thob par 'gyur ba'i gzungs) (sha).

${ }^{44}$ В данном сочинении под термином «четыре неизмеримых» или «четыре безмерные [добродетели]» понимаются «сострадание, доброта, радостность, бесстрастие» [Рерих VII, 1986: 249] (sha).

45 «Жадамва» - это монголизированное произношение тиб. brgyad stong ра букв. '8 тысяч'. Здесь исследователь очень тонко передает по-русски назначение этой дхарани «для восприятия»; мы передаем название этого сочине- 


\section{[c. 3]}

Святое для усвоения обыденного ${ }^{46}$. Сутра для чтения, устанавливающая основу ${ }^{47}$.

Сутра для запоминания о иаре Созериания ${ }^{48}$.

«Святая, заботямаяся о каждом (.) $)\rangle^{49}$.

Сутра для чтения о святом татхагате Лангкар ${ }^{50}$.

10) Сущность мыслей Ваджрабхайра$B b^{51}$.

Стремление к познанию - полет к святости ${ }^{52}$.

ния как «Дхарани о постижении „8-тысячной Праджняпарамиты“» (sha).

${ }^{46}$ При переводе титула данного сочинения (тиб. 'phags pa phal bo (=po) che bzung bar 'gyur ba) В. О. Поляев слову phal подобрал эквивалент «обыденный», в то время как словосочетанием phal po che передается санскритское avatamssaka «назв. раздела Канджура (Кангьюра)» [Рерих VI, 1986: 34]. Поэтому данное название сочинения, на наш взгляд, можно перевести как «Изучение „Аватамсаки“”. Здесь имеется в виду большое собрание сутр (или «Буддха-аватамсака-сутра», букв. 'Сутра цветочной гирлянды'), содержащее важные концепции ранних школ Махаяны (sha).

47 Так передано название «Гандавьюха-сутры» (тиб. 'phags pa sdong po bkod pa'i mdo bklags par 'gyur ba), которая является заключительной частью «Буддха-аватамсака-сутры», о которой было сказано в предыдущем примечании. «Гандавьюха-сутра» является одной из наиболее важных махаянских сутр (sha).

48 При передаче названия этого сочинения (тиб. 'phags pa ting nge 'dzin rgyal po'i mdo bzung bar 'gyur ba 'Самадхираджа-сутра') исследователь прибегает к буквальному переводу (sha).

49 Здесь имя богини Махапратисары (тиб. so sor 'brang ma), одной из пяти великих защитниц, передано описательно (sha).

${ }^{50}$ Так передано название сочинения «Сутра о нисхождении на Ланку» или «Ланкаватарасутра» (тиб. 'phags pa langkar gshegs pa'i mdo bklags par 'gyur ba) (sha).

${ }^{51}$ В перевод титула данного сочинения (тиб. 'phags pa rdo rje 'jigs byed kyi snying po 'Сущность (сердце) Ваджрабхайравы’) В. О. Поляев вводит дополнительное поясняющее слово (Сущноость мысслей) (sa).

52 Так передано название сочинения «Арья-драмида-видьяраджа» (тиб. 'phags pa 'gro lding ba'i rig sngegs (=sngags) 'Видьямантра (мантра знания) Парящего [в небе]') (sa).
11) «Обильный круговой дождь из облачной реки» $»^{53}$.

12) Сущчность планет ${ }^{54}$.

13) Сущность слова ${ }^{55}$.

14) Алмазный клюв ${ }^{56}$.

15) Алмазно-железный клюв неба ${ }^{57}$.

16) Железный клюв ${ }^{58}$.

17) Черный железный клюв (божество) $)^{59}$

18) Красный медный клюв ${ }^{60}$.

19) Божество-докшит «Камчу-нагпо» (черноклювая) ${ }^{61}$.

20) Совершеннейший Глаз 22

21) Глаз, исцеляющий болезни ${ }^{63}$.

22) $И т . \partial$.

В год железной овиь третьего осеннего месяиа в день земляного хайныка изарь (хан) Кархи во дворие Потала ... ${ }^{64}$

[Маргиналии слева сделаны ручкой: Ф-8. Опись 1. № 94. 189 л. $(54,5 \times 12)]$.

${ }^{53}$ Тиб. 'phags pa sprin chen pa (=po) las klung (=rlung) gi dkyil 'khor char rab tu dbab pa ('Вызывающая дождь мандала из Сутры «Великое облако»') (ha).

${ }^{54}$ Тиб. gza' yum ('Мать планет') — под таким названием представлено в содержании 1-го тома «Дхарани „Мать планет“"» (А).

${ }^{55}$ Тиб. skar yum ('Мать созвездий'). Здесь и далее мы приводим тибетские названия сочинений согласно гарчаку в транслитерации и в нашем переводе [Музраева 2018а].

${ }^{56}$ Тиб. 'phags pa rdo rje'i mchu ('[Обладающий] клювом-ваджрой’) (ki).

${ }^{57}$ Тиб. rdo rje gnam lcags mchu ('Небесный железный клюв-ваджра') (ku).

58 Тиб. 'phags pa lcags mchu ('Железный клюв') (ko).

${ }^{59}$ Тиб. 'phags pa lcags mchu nag po ('Черный железный клюв') (khi).

${ }^{60}$ Тиб. 'phags pa zangs mchu dmar po ('Kpacный медный клюв') (khu).

${ }^{61}$ Тиб. 'phags pa kha mchu nag po zhi bar byed ра ('Устраняющая вину «черного» языка' (или 'Камчу Нагпо') (khe).

${ }_{62}$ Тиб. 'phags pa mig rnam par sbyong ba ('Полностью очищающее глаза') (kho).

${ }^{63}$ Тиб. mig nad rab tu zhi ba ('Наилучшим образом успокаивающее болезни глаз') (kho).

64 Здесь приводятся сведения из колофона гарчака, который в данном случае был помещен в конце 1-го тома «Сундуя»: тиб. khar hi'i rgyal po lcags mo lug gi lo | ston zla gsum pa'i gza' skar mdzo mas pa'i dus [gZungs 'dus I. Колофон гарчака: л. 4-5]. 
TOM II [gZungs 'dus II]. — \{Праджняпарамита. Собрание в шлоках $\}^{65}$ общее название то же, что и в предыдущем томе. Ксилограф китайского издания, формат большой тибетский. Объем 193 л. (потхи). Название по 1 листу:

1) «Праджняпарамита - собрание в шлоках (стихах)»"

2) «Праджняпарамита Ваджрачхети$\kappa a-$ сутра (Дордже Цодпа $\left.{ }^{67}\right){ }^{68}$.

3) «Ваджра-бхатха-праджняпарамита-бодхи-нама».

Сутра Дордже-Цодпа - рассчитывающая степени путей к святости.

\section{[c. 4]}

4) Махаянская сутра «Средоточие не$\sigma a »^{69}$

5) Бхами-сутра (Сутра о земле $)^{70}$.

6) Сурья-сутра (Сутра о солние) $)^{71}$

7) Чанда-сутра (Сутра о луне $)^{72}$.

8) Сутра о том, как мальчик просил богатства у Луныз ${ }^{73}$.

Ит. д.

Колофон тот же.

Данное сочинение (2 тома из них) представляют большую научную иенность как памятник на одном из диалектов тибетского языка ${ }^{74}$.

${ }^{65}$ Название сочинения в переводе на русский язык вписано карандашом выше от строки печатного (машинописного) текста, поэтому мы помещаем его в фигурные скобки.

${ }^{66}$ Тиб. tshigs su bcad pa gcig pa| gnyis pa| gsum pa| bzhi pa ('Собрание шлок (стихотворных строф) с 1-й по 4-ю') (ju).

67 «Дордже Цодпа» - это монголизированное произношение сокращенного названия сутры (тиб. rdo rje gcod ра букв. 'Алмазный резак').

${ }^{68}$ Тиб. "phags pa shes rab kyi pha rol tu phyin pa rdo rje gcod pa ('Ваджрачхедика' или 'Алмазная сутра') (je).

${ }^{69}$ Тиб. nam mkha'i snying po'i mdo ('Сутра Акашагарбхи' или 'Средоточия неба'). Акашагарбха - один из восьми главных бодхисаттв [Рерих III, 1985: 258] (jo).

${ }^{70}$ Тиб. sa'i mdo ('Сутра земли') (nyi).

${ }^{71}$ Тиб. nyi ma’i mdo ('Сутра Солнца') (tu).

${ }^{72}$ Тиб. zla ba'i mdo ('Сутра Луны') (tu).

${ }^{73}$ Тиб. khye'u rin chen zla bas zhus pa (te).

${ }^{74}$ Такой вывод сделан на том основании, что в тексте ксилографа имеются значительные расхождения с классическим тибетским языком. Но они затрагивают лишь внешнюю, графическую сторону и касаются внешнего оформления (на-
Как явствует из колофона, сочинение составлено Таранатой для китайского двора, издано в Цищикаре (провинция Хэйлунизян).

Пагинация тибетская и китайская. Названия глав даются на китайском, тибетском, санскрите и монгольском языках (на тибетской графике).

Обращает на себя внимание особенность написания отдельных слов, свидетельствующая о том, что сочинение написано не на классическом лхасском диалекте, а на одном из диалектов ${ }^{75}$.

$B$ каталоге этого двухтомника даны необходимые сведения о сочинениях «Манджушри нама самгити», «Ценд-Аюуш», «Юм», «Праджняпарамита» и др.

По содержанию 1-й том более обширный, содержит некоторые сведения по мифологии, космогонии, астрономии, а также некоторые сюжеты из джатак.

$$
\begin{gathered}
<\ldots> \\
\text { [подпись] }
\end{gathered}
$$

М. н. с. сектора монголоведения В. О. Поляев

\section{Выводы}

Таким образом, описанный материал позволяет составить представление о круге источников, поступивших еще от одного калмыцкого священнослужителя Э. Б. Убушиева (или Агван Табдана). До сих пор мы большей частью основывались на коллекции Тугмюд-гавджи, составляющей основу архивного собрания рукописных и печатных текстов КалмНЦ РАН.

Данная публикация позволяет также дать оценку усилиям, деятельности молодого исследователя, оставившего первое подробное описание части коллекции Э. Б. Убушиева, сумевшего правильно оценить ее значимость.

Старописьменные материалы архива КалмНЦ представляют для исследователей-источниковедов большое поле деятельности. Собранные и сохраненные калмыцкими гелюнгами (Тугмюд-гавджи, Э. Б. Убучертания) графем, выполненных резчиками. В тексте очень много ошибочных начертаний, вот почему В. О. Поляев решил, что это влияние диалектных особенностей языка.

75 Это замечание В. О. Поляева требует специального исследования с привлечением данных диалектов тибетского языка. 
шиев и др.), они донесли до наших дней живое свидетельство бытования буддийской культуры у калмыков на всем протяжении $\mathrm{XX}$ в. Большой заслугой этих священнослужителей-подвижников было то, что, согласно их желанию, эти материалы поступили в академический институт, поскольку они нисколько не сомневались и верили в то, что именно ученые-монголоведы и тибетологи смогут донести информацию о них до широких кругов исследователей и интересующихся буддизмом и сохранить ее для народа. Именно таким был востоковед В. О. Поляев, который стал первым исследователем, получившим возможность ознакомиться с этими ценными письменными источниками на тибетском языке, описать их, дать им оценку, составить первую документацию.

\section{Источники}

gZungs 'dus I - Byin brlabs dngos grub ba bra (=bkra) shas (=shis) cha sar (=char) bebs (='bebs) pa'i / / bstan 'gros (2) phan bde 'di phyang tshal rgyas pa'i phyir / ngo mtshar 'jam gling sa steng dkon pa'i mchog / (3) gzungs mdo brgya dang drug bcu rtsa ldan bzhugs sto [=so]. «Сундуй». Том 1. Разделы ka-ji. Научный архив КалмНЦ РАН. Ф. 8. Оп. 1. Ед. хр. 93. 203 л. Поступил от Э. Б. Убушиева в 1971 г.

gZungs 'dus II - Byin brlabs dngos grub ba bkra sh[i]s cha sar bebs pa'//bstan 'gros (2) phan bde 'di phyang tshal rgyas pa'i phyir / ngo mtshar 'jam gling sa steng dkon mchog gzungs mdo brgya dang drug bcu rtsa ldan bzhugs sto (=so). «Сундуй». Том 2. Разделы ju-pho. Научный архив КалмНЦ РАН. Ф. 8. Оп. 1. Ед. хр. 94. 189 л. Поступил от Э. Б. Убушиева в 1971 г.

\section{Sources}

Byin brlabs dngos grub ba bra (=bkra) shas (=shis) cha sar (=char) bebs (='bebs) pa'i / / bstan 'gros (2) phan bde 'di phyang tshal rgyas pa'i phyir / ngo mtshar 'jam gling sa steng dkon pa'i mchog / (3) gzungs mdo brgya dang drug bcu rtsa ldan bzhugs sto [=so]. gZungs 'dus Collection. Sections: ka-ji. In: Scientific Archive of the Kalmyk Scientific Center of the RAS. Fond 8. Ser. 1. It. 93. 203 p. Donated by E. Ubushiev in 1971. (In Tib.)

Byin brlabs dngos grub ba bkra sh[i]s cha sar bebs $\mathrm{pa} / /$ bstan 'gros (2) phan bde 'di phyang tshal
Опись-справка, которую мы представили в данной работе, свидетельствует о нем как о специалисте высокой квалификации, широкой эрудиции, его переводы с тибетского демонстрируют его профессионализм, а также яркий талант переводчика, не лишенного поэтического дара.

Подводя итог сказанному, подчеркнем, что документы, составленные В. О. Поляевым (Чуматовым), демонстрируют тот большой интерес, с которым руководство института относилось к буддийскому наследию калмыков. Речь идет о периоде начиная с 1960-х гг., периоде восстановления деятельности Института, всех его составляющих, когда после периода депортации встал вопрос о восстановлении и пополнении научных фондов Института.

rgyas pa'i phyir / ngo mtshar 'jam gling sa steng dkon mchog gzungs mdo brgya dang drug bcu rtsa ldan bzhugs sto (=so). gZungs 'dus Collection. Sections: ju-pho. In: Scientific Archive of the Kalmyk Scientific Center of the RAS. Fond 8. Ser. 1. It. 94.189 p. Donated by E. Ubushiev in 1971. (In Tib.)

\section{Литература}

Буддийская традиция 2008 - Буддийская традиция в Калмыкии в XX веке: памяти О. М. Дорджиева (Тугмюд-гавджи). 18871980. Элиста: КИГИ РАН, 2008. 190 с.

Музраева 2018а - Музраева Д. Н. Из истории бытования сборника буддийских текстов «Сундуй» у калмыков (на материале коллекции Э. Б. Убушиева, хранящейся в научном архиве КалмНЦ РАН) // Oriental Studies. 2018. № 3. С. 68-94.

Музраева 20186 - Музраева Д. Н. Коллекция тибетских и монгольских письменных источников Калмыцкого научного центра РАН, поступившая от Э. Б. Убушиева. Штрихи к портрету фондообразователя по дарственным записям // Вестник архивиста. 2018. № 4. С. 1206-1216.

Музраева 1999 - Музраева Д. Н. Памятники тибетского фонда, хранящиеся в архиве Калмыцкого института гуманитарных и прикладных исследований // Культура Центральной Азии: письменные источники. Вып. 3. Улан-Удэ: Изд-во БНЦ СО РАН, 1999. С. 189-192. 
Орлова 2002 - Орлова К. В. Описание монгольских рукописей и ксилографов, хранящихся в фондах Калмыкии // Бюллетень Общества востоковедов. Вып. 5. М.: ИВ РАН, КИГИ PAH, 2002. 85 c.

Рерих VII, 1986 - Тибетско-русско-английский словарь с санскритскими параллелями. Вып. VII. М.: Наука, ГРВЛ, 1986. 311 с.

Рерих VI, 1986 - Тибетско-русско-английский словарь с санскритскими параллелями. Вып. VI. М.: Наука, ГРВЛ, 1986. 373 с.

Рерих III, 1985 - Тибетско-русско-английский словарь с санскритскими параллелями. Вып. ІІІ. М.: Наука, ГРВЛ, 1985. 432 с.

Чуматов 1983 - Чуматов В. О. Старописьменные памятники КНИИИФЭ // Монголоведные исследования. Элиста: КНИИИФЭ, 1983. С. 116-131.

\section{References}

[A Tibetan-Russian-English Dictionary with Sanskrit Parallels]. Roerich Yu. (comp.). Is. VII. Moscow: Nauka, 1986. 311 p. (In Russ., Tib., Eng.)

[A Tibetan-Russian-English Dictionary with Sanskrit Parallels]. Roerich Yu. (comp.). Is. VI. Moscow: Nauka, 1986. 373 p. (In Russ., Tib., Eng.)

[A Tibetan-Russian-English Dictionary with Sanskrit Parallels]. Roerich Yu. (comp.). Is. III. Moscow: Nauka, 1985. 432 p. (In Russ., Tib., Eng.)

[Kalmykia's Buddhist Tradition in the $20^{\text {th }}$ Century: Commemorating O. Dordzhiev (Tyugmyud
Gavji). 1887-1980.]. Elista: Kalm. Hum. Res. Inst. of RAS, 2008. 190 p. (In Russ.)

Chumatov V. O. Old written monuments contained in the Kalmyk Research Institute of History, Philology and Economics. In: [Collected Mongol Studies]. Elista: Kalm. Res. Inst. of Hist., Phil. and Econ., 1983. Pp. 116-131. (In Russ.)

Muzraeva D. N. About the collection of Tibetan and Mongolian written sources donated to the Archive of the Kalmyk Scientific Center of the RAN by E. B. Ubushiev: using donation inscriptions to touch up the portrait of donator. Herald of an Archivist. 2018. No. 4. Pp. 12061216. (In Russ.)

Muzraeva D. N. Monuments of the Tibetan Fond contained in the Archive of the Kalmyk Institute for Humanities and Applied Research. In: [Culture of Central Asia: Written Sources]. Is. 3. Ulan-Ude: BSC SB RAS Publ., 1999. Pp. 189-192. (In Russ. and Tibetan)

Muzraeva D. N. The gZungs 'dus Buddhist texts collection: excerpts from the history of its existence among the Kalmyks (a case study of E. B. Ubushiev's collection from the Archive of the Kalmyk Scientific Center of the RAS). Oriental Studies. 2018. No. 3. Pp. 68-94. (In Russ.)

Orlova K. V. A description of Mongolian-language manuscripts and xylographs contained in Kalmykia's fonds. In: [Society of Orientalists: Newsletter]. Is. 5. Moscow: Inst. of Oriental Studies of RAS, Kalm. Hum. Res. Inst. of RAS, 2002. 85 p. (In Russ.) 